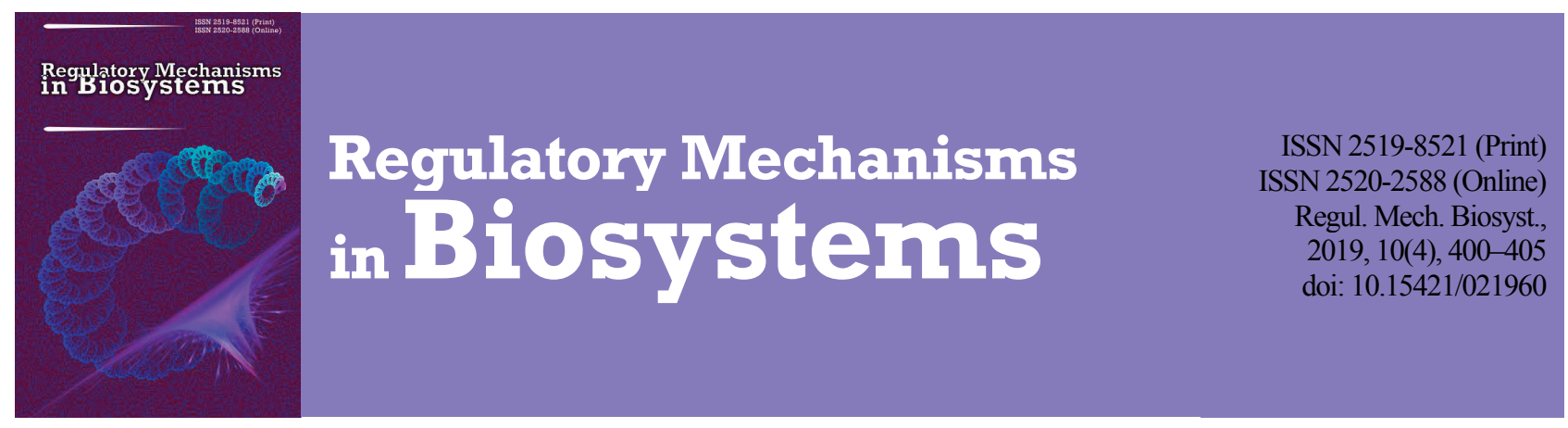

\title{
Assessment of phenotypic and storage protein diversity in exotic barley cultivated in District Dir (Pakistan)
}

\author{
M. Ali*, M. Nisar**, W. Khan**, T. Naz**, S. U. Zaman*, M. Hussain* \\ *Hazara University, Mansehra, Pakistan \\ **University of Malakand, Chakddara, Pakistan
}

Article info

Received 14.10.2019

Received in revised form 12.11.2019

Accepted 13.11.2019

Hazara University,

Mansehra, 21120, Khyber

Pakhtunkhwa, Pakistan.

University of Malakand,

Chakddara, 18800, Khyber

Pakhtunkhwa, Pakistan.

Tel.: +92-346-934-29-56.

E-mail:

muradsahil77@gmail.com,

mhussainpk8@yahoo.com

\author{
Ali, M., Nisar, M., Khan, W., Naz, T., Zaman, S. U., Hussain, M. (2019). Assessment of phenotypic and storage protein diversity \\ in exotic barley cultivated in District Dir (Pakistan). Regulatory Mechanisms in Biosystems, 10(4), 400-405. doi:10.15421/021960
}

A total of 198 exotic barley genotypes were collected from the Gene Bank of the Plant Genetic Resource Institute (PGRI), National Agriculture Research Center (NARC), Islamabad, Pakistan, for the assessment of genetic diversity based on morphological and seed storage proteins. Qualitative and quantitative traits were noted as per IPGRI, 1994 descriptor. Among the quantitative parameters, a high level of genetic variability index was noted in seeds per spike at $79.9 \%$ of coefficient of variance followed by biomass per plant which shows $37.4 \%$ variance, while minimum variance in quantitative traits was noted in days to germination at $5.4 \%$ followed by days to maturity at 3.1\% with average mean genetic variation in all quantitative traits at $97.6 \%$. Assay of total seed protein in these exotic accessions was analogue through polyacrylamide gel electrophoresis. A high level of variation was noted in loci (bands) B26 (0.98\%) followed by B25 (0.89\%), B24 (0.78\%),B23 (0.69\%) and B01 $(0.52 \%)$. A similarly low level of variation was detected in B03 (0.16\%) followed by B06 (0.18\%), B13 (0.19\%), B12 (0.21\%), B11 (0.23\%), B05 (0.24\%), B07 (0.25\%), B21 $(0.34 \%), \mathrm{B} 20(0.35 \%), \mathrm{B} 17(0.39 \%)$. The results indicate that the mean value of variation in these accessions is $97.6 \%$. Further assessments and exploration were suggested for these genotypes in multi-climatic zones to satisfy farmers' need, breeders' interest and malt-industrial requirements.

Keywords: Hordeium vulgare; genetic variability; morphology; polyacrylamide gel electrophoresis.

\section{Introduction}

Barley is economically significant, mostly for the production of malt and food. The value of this crop has increased due to its consumption as a functional food with a range of beneficial effects on health (Hua et al., 2015). Application of barley such as malt in brewing, animal feed, human consumption and the distilling industry make it a globally important crop. The long process of breeding has given rise to an increase in diversity of barley varieties (Ivandic et al., 2003). Cultivators choose the best variety of barley according to specific climate and its applications such as the distilling industry, human consumption, animal feeding and malt preparation (Ferreira et al., 2016). Genetic diversity incorporates new feasible sources in plant breeding to continue increasing the grain yield, plant height and quality. There have been many studies involving testing of barley diversity through many parameters in which genetic diversity in both wild and cultivated barley has been reported (Baik \& Ullrich, 2008; Yahiaoui et al., 2008; Ledovskoy et al., 2010; Khodayari, 2012; Nandha \& Singh, 2014).

Barley (Hordeium vulgare L.) belongs to the genus Hordeium of the grass family; the plant height is from 20 to $60 \mathrm{~cm}$. The barley plant's stem is erect and hollow, with cylindrical internodes, each node bearing leaves; two types of root system have been found, seminal and adventitious. Leaves produced on the stem are alternate and about 5-15 mm wide. The structure of the leaves is composed of ligules, sheath blade and auricle. Barley differs from other cereal crops due to its smooth auricle and ligule that envelop the stem and have anthocyanin pigment (Gomez-Macpherson, 2001). Barley has oval shape grain, which narrows at each end. Protective exterior husks are present surrounding the grain while huskless varieties of barley are also found. However the huskless varieties are not appropriate for agriculture (Derbew et al.,
2013). Barley (H. vulgare L.) is one of the major crops of the world; barley is a rich source of carbohydrates $(80 \%)$ and energy. The ancient Romans also used barley for energy. Gladiators were fed on barley so they were called "hordeari" from hordeium.

Researchers have found that due to consistency of non-starch polysaccharides in barley, also known as glucans, it is able to lower the blood serum cholesterol level in humans (Weber et al., 1991). The barley grain comprises approximately $10-17 \%$ protein, $2-3 \%$ lipids, 65 $68 \%$ starch (main carbohydrate), $1.5-2.5 \%$ minerals and about $4-9 \%$ B glucans while soluble dietary fibers present $3-20 \%$ in total of $11-$ $34 \%$ dietary fibers. B glucans are the major non-starch polysaccharides in barley grain (Tsen, 1985; Marathée \& Gomez-MacPherson, 2001). On the basis of production, after wheat, maize and rice, barley is considered the fourth most important cereal crop of the world and was ranked in the list of top ten crop plants in the world. Barley grows well in the cool season, the optimum temperature for its growth is about 15$30{ }^{\circ} \mathrm{C}$. About $59 \%$ and $14 \%$ of total barley is used as feed and in industries, respectively (Toivonen et al., 2013). Similarly, it has been used to resolve the taxonomic and evolutionary problems of several plants (Vapa \& Radovic, 1998; Ali et al., 2018) due to high polymorphism. Recently, both wild and cultivated barley have been characterized on the basis of seed storage protein by using SDS-PAGE. The aim of this assay is adaptation and release of new cultivars superior in their yield contributing traits and having the ability of adapting to climate.

\section{Materials and methods}

For the present research assay, 198 exotic accessions of $H$. vulgare $\mathrm{L}$. were selected from the Gene Bank of PGRI (Plant Genetic Resources Institute) NARC (National Agriculture Research Center) Islamabad, Pa- 
kistan. The catalogue sorted information shows that these selected accessions are from other agro-climate countries i.e. Japan, China, Iran, Cyprus, Syria, and the USA, which represents a wide range of ecological zones from dry mountains to irrigated plains.

Morphological characterization. During the present research work, a total of 26 morphological traits were observed in order to assess genetic diversity. The morphological traits were divided into qualitative and quantitative traits. A total of 17 qualitative traits include growth habit, stem pigmentation, auricle pigmentation, photoperiod sensitivity, kernel covering, spike density, aleurone colour, grain colour, lemma colour, lemma awn, lemma awn barbs, awn colour, glume and awn. glume colour, lemma type, length of rachilla hairs, row number. 9 quantitative traits include day to germination, days to flowering, days to maturity, plant height, biomass per plant, seed per spike, spike length, 100 seed weight and harvest index.

Biochemical characterization. For protein extraction five healthy seeds from each genotype were taken for polyacrylamide gel electrophoresis through SDS-PAGE. The grain was ground to fine powder, $0.3 \mathrm{~g}$ of powder was taken from each sample. We added $700 \mu \mathrm{L}$ protein extraction buffer and vertex to homogenize. The powder was centrifuged at $15000 \mathrm{rpm}$ for 40 minutes at $40{ }^{\circ} \mathrm{C} .12 .5 \%$ polyacrylamide gel containing separation gel (0.4\% SDS, 3M Tris-HCL and $\mathrm{PH} 9)$ and stacking gel (0.4\% SDS, 0.4M Tris-HCL, PH 3.4) were used.0.125\% SDS, $129 \mathrm{M}$ Glycine, $0.025 \mathrm{M}$ Tris and run on $80 \mathrm{~V}$ for $5 \mathrm{hrs}$. The gel was then kept in de-staining solution for 8 hours, until the blue background disappeared and bands become visible. The data were analyzed on SPSS 16.0 and Statistica 10.

\section{Result}

A total of 26 agro-morphological characters were studied, which are further divided into qualitative and quantitative traits. The 9 quantitative traits include days to germination, days to flowering and maturity, 100 seed weight, spike length, seed per spike, plant height, plant biomass, and harvest index. The 17 qualitative traits include growth habit, stem pigment, auricle pigmentation, photoperiod sensitivity, spike density, lemma awn, lemma type, lemma colour, glume and awn, glume colour, lemma awn barbs, awn colour, kernel covering, grain colour, length of rachilla hairs, alurone colour and row number.

Qualitative traits. In the present research work 17 qualitative traits were noted. Growth habit, in total $17.04 \%$ landraces showed erect growth and $16.52 \%$ had intermediate growth type while prostrate growth type was observed in $0.00 \%$ landraces. Three types of pigment were observed on the stem i.e. green, basal purple and more purple. In the total of 198 alien genotypes, $16.18 \%$ showed basal purple pigmentation, $14.99 \%$ showed green and $2.21 \%$ showed more purple type of stem pigmentation. $28.61 \%$ showed green pigmentation, $1.70 \%$ had pale purple, $1.70 \%$ showed purple and $1.02 \%$ showed dark purple pigmentation in the auricle. Photoperiod sensitivity of plants was grouped into four categories i.e. low, very low, intermediate and very high. $28.45 \%$ of plants showed intermediate sensitivity, $2.56 \%$ showed very high, $2.56 \%$ low, while very low was shown by $0.00 \%$ plants. On the basis of frequency and percentage distribution, spike density was divided into three categories i.e. weak, intermediate and high. $15.33 \%$ showed intermediate spike density, $14.31 \%$ had weak while $3.75 \%$ landraces showed high density. In total 198 accessions of barley lemma awn were also observed. In these $20.61 \%$ had awns, $12.61 \%$ awnlets while $0.00 \%$ were awnless. Three types of lemma awn barbs were observed, smooth, intermediate and rough. A total of $33.39 \%$ had rough, $0.17 \%$ had intermediate while $0.00 \%$ had smooth lemma awn barbs.

On the basis of frequency and percentage distribution glume and awn were divided into four categories i.e. length of glume and awn shorter than kernel, length of glume and awn longer than kernel, glume plus awn shorter than kernel, glume plus awn twice as long as kernel. $16.35 \%$ had glume length and awn longer than kernel, $4.26 \%$ glume plus awn shorter than kernel, $1.36 \%$ length of glume and awn shorter than kernel and $0.85 \%$ glume plus awn twice as long as kernel. In case of glume colour there was no variation found. All the landraces showed white colour of glume. In the 198 lines, three types of lemma were observed. $27.26 \%$ had lemma teeth, $2.90 \%$ showed lemma hair and
$0.34 \%$ had no lemma teeth. Four types of awn colour were observed. On the basis of frequency and percentage distribution $21.12 \%$ showed amber/white colour, $6.64 \%$ showed yellow colour, $4.77 \%$ showed reddish colour $1.02 \%$ showed brown while black colour was found in $0.00 \%$.In total of 198 accessions of barley $19.93 \%$ showed long rachilla hairs while $13.62 \%$ had short rachilla hairs. Kernel covering was divided into three categories i.e. naked grain, semi covered grain and covered grain. $2.39 \%$ had naked grain and $31.81 \%$ had covered grain while semi covered grain was observed in $0.00 \%$. $31.86 \%$ showed white grain colour, $0.85 \%$ showed purple colour, $0.34 \%$ had red colour of grain and $0.51 \%$ had black grain colour. No variation was found in aleurone colour. All were white in colour.

Quantitative traits. Days to germination of barley was divided into three categories (low intermediate and high), the minimum number of days to germination was 130 while the maximum was 155 with mean value 140.2 , sample variance 57.8 and standard deviation 7.60 . In case of days to flowering, the samples were placed into three categories (low, intermediate and high) the maximum range for days to flowering was 22 while minimum range was 9 with sample variance 5.9, standard deviation 2.43 and mean value 9.7. 100 seed weight also divided into three categories (low intermediate and high) the minimum was 29.2 while the maximum was 90 with mean value 58.8, standard deviation 13.78 and sample variance 189.8 . The category seeds per spike was divided into three subcategories (low, intermediate and high) maximum was 840 while minimum was 18 with sample variance 3496.5 , standard deviation 59.13 and mean value 74.0. For spike length the samples were divided into three categories (low intermediate and high) minimum range was 9 while maximum range was 914 with mean value 14.2, sample variance 4135.0 and standard deviation 4135.0. Plant height of samples was divided into three categories (low intermediate and high) minimum range for plant height was range was 3 while maximum range was 55 with mean value 41.4 , sample variance 48.2 and standard deviation was 6.94. In case of biomass per plant, the samples were placed into three categories (low intermediate and high), maximum was 484.4 while minimum range was 4 with sample variance 3168.9 , standard deviation 56.3 and mean value 150.6. Days to maturity was also divided into three categories (low intermediate and high), maximum range for days to maturity was 186 while minimum range from 165 with mean value 180.9, standard deviation was 5.7 and sample variance was 62.2. Harvest index of barley landraces was divided into three categories (low, intermediate and high) minimum range was 9.75 while maximum range was 2100 with sample variance 23235.5, standard deviation 152.4 and mean value (Table 1).

Table 1

Descriptive statistics for nine quantitative traits of 198 exotic barley accessions

\begin{tabular}{|c|c|c|c|c|c|c|c|}
\hline \multirow[b]{2}{*}{ Traits } & \multirow[b]{2}{*}{ Mean } & \multirow{2}{*}{$\begin{array}{l}\text { Standard } \\
\text { error }\end{array}$} & \multirow{2}{*}{$\begin{array}{l}\text { Standard } \\
\text { deviation }\end{array}$} & \multirow{2}{*}{$\begin{array}{c}\text { Sample } \\
\text { variance }\end{array}$} & \multicolumn{2}{|c|}{ Range } & \multirow[b]{2}{*}{$\mathrm{CV}, \%$} \\
\hline & & & & & $\begin{array}{l}\text { mini- } \\
\text { mum }\end{array}$ & $\begin{array}{l}\text { maxi- } \\
\text { mum }\end{array}$ & \\
\hline$\overline{\mathrm{DG}}$ & 140.2 & 0.54 & 7.60 & 57.8 & 130 & 155 & 5.42 \\
\hline DF & 9.7 & 0.17 & 2.43 & 5.9 & 9 & 22 & 25.11 \\
\hline $100 \mathrm{~W}$ & 58.8 & 0.98 & 13.78 & 189.8 & 29 & 90 & 23.41 \\
\hline $\mathrm{S} / \mathrm{S}$ & 74.0 & 4.20 & 59.13 & 3496.5 & 18 & 840 & 79.88 \\
\hline SL & 14.2 & 4.57 & 64.30 & 4135.0 & 4 & 914 & 452.46 \\
\hline $\mathrm{PH}$ & 41.4 & 0.49 & 6.94 & 48.2 & 3 & 55 & 16.77 \\
\hline $\mathrm{B} / \mathrm{P}$ & 150.6 & 4.00 & 56.29 & 3168.9 & 4 & 484 & 37.37 \\
\hline DM & 180.9 & 0.40 & 5.67 & 32.2 & 165 & 186 & 3.14 \\
\hline $\mathrm{HI}$ & 65.0 & 10.83 & 152.43 & 23235.5 & 9.7 & 2100 & $\begin{array}{r}234.50 \\
97.56\end{array}$ \\
\hline
\end{tabular}

Note: DG - days to germination, DF - days to flowering, $100 \mathrm{~W}-100$ seed weight, $\mathrm{S} / \mathrm{S}$ - seed per spike, $\mathrm{SL}$ - spike length, $\mathrm{PH}$ - plant height, $\mathrm{B} / \mathrm{P}$ - biomass per plant, $\mathrm{DM}$ - days to maturity, $\mathrm{HI}$ - harvest index.

Correlation analysis of quantitative traits. Correlation was calculated by using SPSS software for 9 morphological characters of barley accession. In total 36 coefficients of value were observed in which 19 were highly positively correlated while 17 was negatively correlated. The highly positive correlation was observed for days to germination with days to flowering 0.0576 , seeds per spike 0.0537 and harvest index 0.386 . Days to flowering show positive correlation with spike length 
0.104 and plant height 0.045 while 100 seed weight shows positive correlation with plant height 0.225 , spike length 0.059 , biomass per plant 0.096 , seed per spike 0.1066 and harvest index 0.0304 . Spike per plant shows positive correlation with spike length 0.001 , plant height 0.108 and harvest index 0.208 while spike length shows positive correlation with plant height 0.073 , days to maturity 0.049 and harvest index 0.010 . Positive correlation of plant height was observed with biomass per plant 0.209 whereas biomass per plant shows positive correlation with days to maturity 0.011 . The positive correlation of days to maturity was observed with harvest index 0.001 . Highly negative correlation was shown by days to germination with 100 seed weight -0.020 , spike length -0.023 , plant height -0.080 , biomass per plant -0.190 , days to maturity -0.090 (Table 2).

Table 2

Correlation among 9 quantitative traits of 198 exotic barley accessions

\begin{tabular}{lcccccccc}
\hline Traits & DG & DF & $100 \mathrm{~W}$ & \multicolumn{1}{c}{ S/S } & SL & PH & B/P & DM \\
\hline DG & 1 & - & - & - & - & - & - & - \\
DF & 0.056 & 1 & - & - & - & - & - & - \\
100W & -0.020 & -0.027 & 1 & - & - & - & - & - \\
S/S & 0.054 & -0.070 & 0.107 & 1 & - & - & - & - \\
SL & -0.023 & 0.104 & 0.060 & 0.002 & 1 & - & - & - \\
PH & -0.081 & 0.034 & 0.217 & 0.107 & 0.073 & 1 & - & - \\
B/P & -0.194 & -0.017 & 0.094 & -0.001 & -0.084 & 0.223 & 1 & - \\
DM & -0.098 & -0.031 & -0.015 & -0.072 & 0.049 & -0.032 & 0.112 & 1 \\
HI & 0.386 & -0.042 & 0.031 & 0.278 & 0.010 & -0.083 & -0.280 & 0.001 \\
\hline
\end{tabular}

Note: DG - days to germination, DF - days to flowering, $100 \mathrm{~W}-100 \mathrm{seed}$ weight, $\mathrm{S} / \mathrm{S}$ - seed per spike, $\mathrm{SL}$ - spike length, $\mathrm{PH}$ - plant height, $\mathrm{B} / \mathrm{P}$ - biomass per plant, $\mathrm{DM}$ - days to maturity, $\mathrm{HI}$ - harvest index.

Seed storage protein. The protein profile of 198 genotypes of barley was tested through SDS-PAGE which showed 26 reproducible bands. High level of variation was observed in B26 (0.98\%) followed by B25 (0.89\%), B24 (0.78\%), B23 (0.69\%), B01 (0.52\%), B16 (0.50\%) and B22 $(0.42 \%)$. Similarly low level of variation was detected in B03 $(0.16 \%)$ followed by B06 (0.18\%), B13 (0.19\%), B12 (0.21\%), B11 (0.23\%), B05 (0.24\%), B07 (0.25\%), B08 (0.25\%), B19 (0.25\%), B09 (0.26\%), B02 (28\%), B04 (0.31\%), B14 (0.31\%), B15 (0.32\%), B10 (0.33\%), B18 (0.34\%), B21 (0.34\%), B20 (0.35\%), B17 (0.39\%) (Table 3).

Cluster analysis. The genetic tree based on protein binary data matrix divides barley into multiple clusters (Fig. 2) on the basis of variation present in their protein profile. It was observed that the dendrogram delineated accessions into four linkages (L-1, L-2, L-3 and L-4). All the four linkages further consist of 12 clusters. Cluster-1 of Linkage-1 consists of 17 accessions out of 198, in which 2 genotypes come from the USA, 13 genotypes from Japan and 2 from Syria. Cluster-2 of Linkage1 comprises 11 genotypes in which 8 come from Japan while 3 from
Syria. Cluster-3 consists of 17 genotypes out of which 14 come from Japan while 3 come from Syria. Cluster- 4 of the same linkage contains total 6 genotypes including 5 from Japan and 1 from Syria.

Table 3

Total genetic diversity present in 26 bands of exotic barley

\begin{tabular}{|c|c|c|c|c|}
\hline Bands & $\mathrm{F}$ & $\mathrm{P}, \%$ & $\mathrm{~A}, \%$ & TGD, $\%$ \\
\hline$\overline{\mathrm{B} 1}$ & 95.0 & 48.22 & 51.78 & 0.52 \\
\hline B2 & 141.0 & 71.57 & 28.43 & 0.28 \\
\hline B3 & 165.0 & 83.76 & 16.24 & 0.16 \\
\hline B4 & 136.0 & 69.04 & 30.96 & 0.31 \\
\hline B5 & 150.0 & 76.14 & 23.86 & 0.24 \\
\hline B6 & 161.0 & 81.73 & 18.27 & 0.18 \\
\hline B7 & 147.0 & 74.62 & 25.38 & 0.25 \\
\hline B8 & 148.0 & 75.13 & 24.87 & 0.25 \\
\hline B9 & 145.0 & 73.60 & 26.40 & 0.26 \\
\hline B10 & 132.0 & 67.01 & 32.99 & 0.33 \\
\hline B11 & 151.0 & 76.65 & 23.35 & 0.23 \\
\hline B12 & 156.0 & 79.19 & 20.81 & 0.21 \\
\hline B13 & 160.0 & 81.22 & 18.78 & 0.19 \\
\hline B14 & 135.0 & 68.53 & 31.47 & 0.31 \\
\hline B15 & 133.0 & 67.51 & 32.49 & 0.32 \\
\hline B16 & 99.0 & 50.25 & 49.75 & 0.50 \\
\hline B17 & 120.0 & 60.91 & 39.09 & 0.39 \\
\hline B18 & 130.0 & 65.99 & 34.01 & 0.34 \\
\hline B19 & 147.0 & 74.62 & 25.38 & 0.25 \\
\hline B20 & 128.0 & 64.97 & 35.03 & 0.35 \\
\hline B21 & 130.0 & 65.99 & 34.01 & 0.34 \\
\hline B22 & 114.0 & 57.87 & 42.13 & 0.42 \\
\hline B23 & 61.0 & 30.96 & 69.04 & 0.69 \\
\hline B24 & 44.0 & 22.34 & 77.66 & 0.78 \\
\hline B25 & 21.0 & 10.66 & 89.34 & 0.89 \\
\hline B26 & 4.0 & 2.03 & 97.97 & 0.98 \\
\hline
\end{tabular}

Cluster-5 of Linkage-2 comprises 23 genotypes out of the total of 198 lines, in which 1 comes from the USA, 1 from China, 3 from Iran, 3 from Syria and 15 from Japan. Cluster- 6 consists of 14 lines, out of which 11 come from Japan, 2 from the USA and 1 from Syria. Cluster7 of the same linkage had only 17 lines, including 14 from Japan and 3 from Syria.Cluster-8 of Linkage-3 consists of 25 genotypes, out of which 12 come from Japan, 6 from Syria, 6 from Iran and 1 from Cyprus. Cluster- 9 contains a total of 21 genotypes, in which 10 come from Japan, 9 from Syria, 1 from Iran and 1 from Cyprus. Cluster-10 comprises 14 genotypes, in which 8 lines come from Japan, 5 from Syria and 1 from Cyprus. Cluster-11 of the same linkage contain 13 lines including 8 genotypes from Japan, 4 from Syria and 1 from Cyprus. Cluster-12 of Linkage-4 comprises 17 genotypes out of 198, lines in which 15 belong to Japan and 2 are from Syria (Fig. 2).
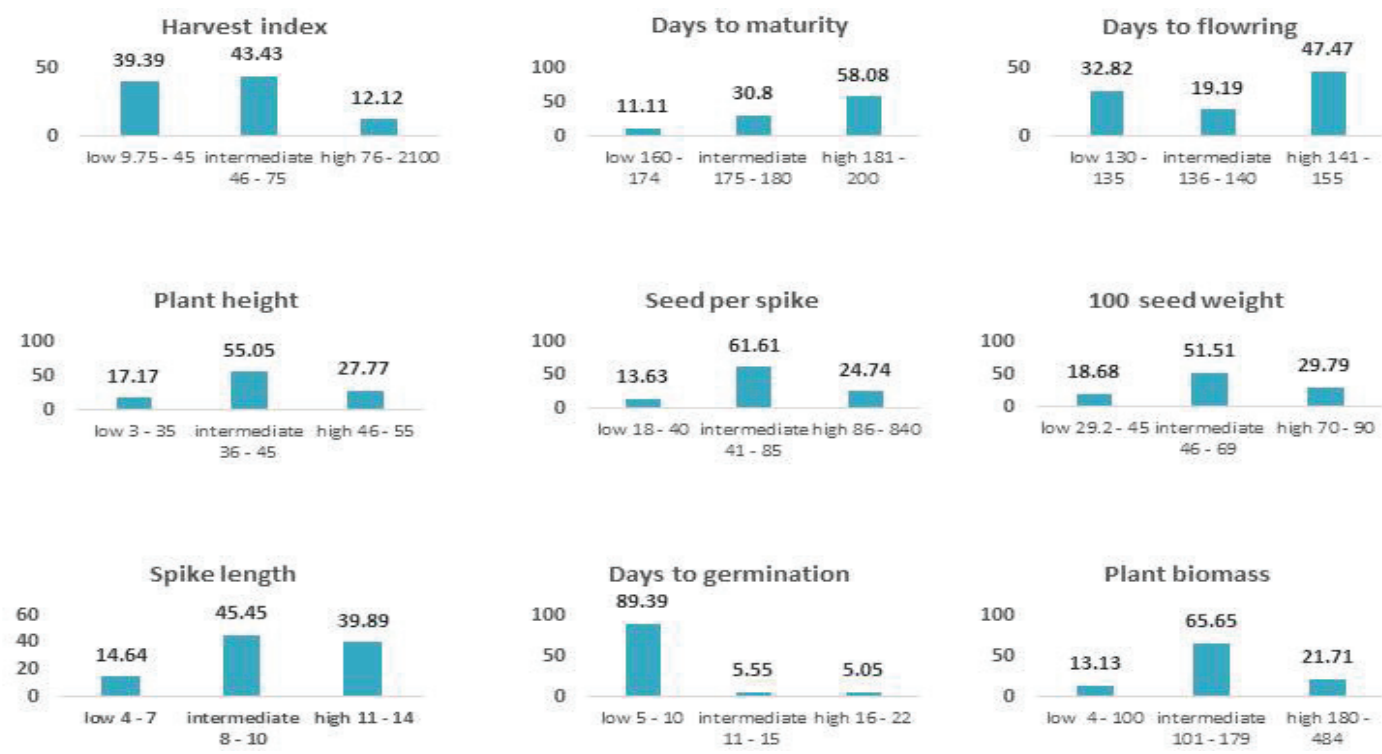

Fig. 1. List of quantitative traits charts noted in 198 exotic barley accessions 


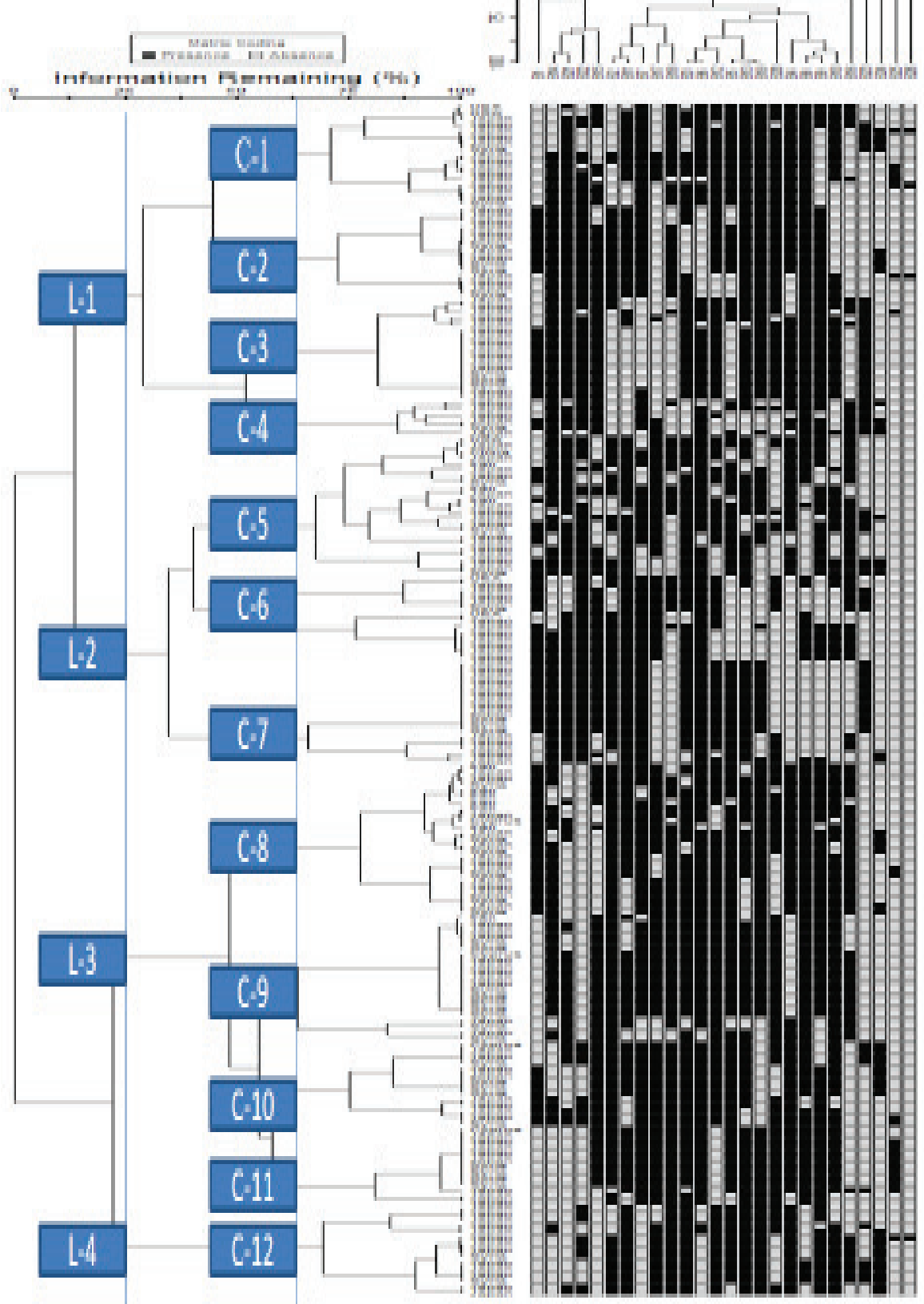

Fig. 2. Two way cluster analysis based on seed storage protein in 198 exotic barley accessions

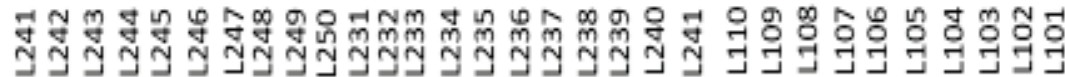

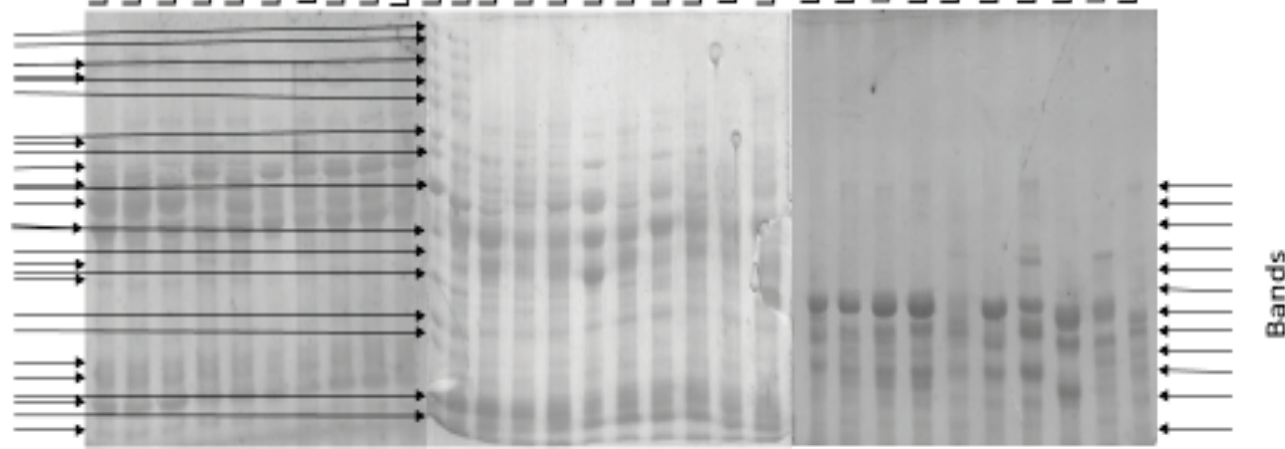

Fig. 4. Gel pic of 198 exotic accessions of barley 


\section{Discussion}

In the present research work, 198 genotypes of barley were assessed to identify genetic variability among genotypes of barley with the help of morphological traits including both qualitative and quantitative traits. A total of 26 morphological traits were studied, out of which there were 9 quantitative traits including days to germination, days to flowering, plant height, spike length, seeds per spike, 100 seed weight, biomass per plant days to maturity and harvest index. The 17 qualitative traits included growth habit, stem pigment, auricle pigmentation, photoperiod sensitivity, spike density, lemma awn, lemma awn barbs, glume and awn, glume colour, lemma type, awn colour, length of rachilla hairs, kernel covering, lemma colour, grain colour, alurone colour and row number.

On the basis of frequency distribution, significant variation was found in qualitative traits except for aleurone colour and glume colour which showed no variation. All the landraces showed white colour of glume and aleurone. In the present research work, photoperiod and spike density were also observed. Two types of growth habit was observed, erect and intermediate. In cases of pigmentation, three types of pigment were observed on the stem; green, basal purple and more purple while on the auricle purple, pale purple and dark purple pigmentation was observed. Three type of lemma was observed in which some had lemma teeth, some showed lemma hair, while some had no lemma teeth. Lemma awn barbs showed three types, smooth intermediate and rough. In the case of awn and lemma colours, four colours were observed including amber/white, yellow, reddish and brown awn while lemma showed normal, purple, red and black colour. According to the present study, the barley accessions had long and short rachilla hairs. With kernel covering, covered grain and naked covered grains were observed. In the present study, white, purple, red and black grain were observed. The results of the present study were strongly supported by the work of Zeeshan et al. (2012), who worked on 151 genotypes of barley for agro-morphological evaluation. A total of 11 qualitative traits were recorded including row type, spike density, glume awn, glume colour, grain colour, awn colour, awn barbs, kernel covering, lemma colour and rachilla hairs.

During the present work a remarkable variability was observed among the different genotypes of barley landraces. A significant variation was reported in spike length $(4-914 \mathrm{~cm})$ and 100 seed weight (29.2-90.0 g) as was also found in the work of (Zeeshan et al., 2012), who reported spike length $11.87-45.17 \mathrm{~cm}$ and 100 seed weight range $1.43-6.76 \mathrm{~g}$. In the present observations, plant height ranges from 3$55 \mathrm{~cm}$ while days to maturity range from 165-186. Similarly (Sipahi et al., 2010) also stated a wide range of variation for plant height 44.9 $94.1 \mathrm{~cm}$, days to maturity ranging $92-131$ and grain yield. During the present research work on barley landraces seeds per spike ranged from $18-840$, biomass per plant 4-484.4, days to germination 130-155, days to flowering ranged from 9-22 and harvest index from 9.75-2100.00. Ebrahim et al. (2015) also reported variability in spike length, number of seeds per spike, plant height, number of spikelets per spike, and weight of seed per spike, days to maturity, thousand seed weight, biomass yield, and grain yield of barley landraces.

Seed storage protein profile is used to solve the evolutionary and taxonomic difficulties of many crops (Ladinzishy \& Hymowitz, 1979). In the present study SDS analysis was done for 198 genotypes, in which total 26 bands were observed and all were polymorphic, as also found in the work of (Sipahi et al., 2010), who observed 15 bands in his experiment on 34 genotypes of barley. Another botanist (Baloch et al., 2014) worked on 90 genotypes of barley and observed 20 bands. (Mzid et al., 2016) also reported 37 bands in his research on barley landraces. In the present study, a high level of variation was observed in B26 $(0.98 \%)$ and B25 $(0.89 \%)$. This variation expresses the genetic diversity present in seed storage protein. This provides an advantage to plant breeders for future breeding activities. Through PCORD software a scatter plot and dendrogram tree was constructed which showed significant variation among the genotypes. PCA divided landraces into multiple groups on the basis of similarity and dissimilarity. In the present study, the dendrogram tree separated landraces into four linkages i.e. L-1, L-2, L-3 and L-
4, which is further divided into 12 clusters. Linkage-1 consists of 4 clusters i.e. cluster-1, cluster-2, cluster-3 and cluster-4. Linkage- 2 consists of 3 cluster i.e. cluster-5, cluster- 6 and cluster-7. Linkage- 3 consists of cluster-8, cluster-9, cluster-10 and cluster-11. Linkage- 4 consists of cluster-12 only. PCA is a multivariate approach used to complement the cluster analysis information and to produce a dimensional scatter plot of the germplasm which is more informative regarding distances among the genotypes (Hassan et al., 2016).

\section{Conclusion}

The aim of present assay is to investigate adaptations of alien genotypes in the climate of Malakand division and Lower Dir district researched by the University of Malakand, Khyber Pakhtunkhwa. The result of our study concluded that, the accessions of $H$. vulgare L. exotic gene pools shows great genetic diversity within their agro-morphometric parameters and also within total seed storage protein profile assay detected through polyacrylamide gel electrophoresis SDS-PAGE technology. The diverse genetic population provides maximum opportunity for cereal breeders to select persistent, genomic insistent genotype/accession. Genetic diversity was assessed in this study through polyacrylamide base SDS-PAGE technique, which shows that the greatest genetic diversity was in loci/band number B26 (0.98\%) and the least diversity was observed in loci number three $(\mathrm{B} 03=0.16)$. After evaluating and sorting the gene pool of 198 exotic accessions, 40 accessions were considered as novel accessions from China, Japan and America, because these accessions are unique in their qualitative and yield contributing traits. These forty accessions also reproduce 26 protein bands markers on the electropherogram of the gel electrophoresis technique. The present study also revealed that SDS-PAGE is not only helpful for assessment of genetic diversity. DNA base markers and other spectrometric based techniques and multivariate agro-climate trials are needed for further assessment to find and conserve the gene pool index and enhance genetic diversity for crop improvement, which is needed in the context of climate changes and germplasm conservation.

The authors wish to thank Dr. Abdul Ghafoor, Director General of Plant Genetic Resources, for providing the exotic genotypes from The Gene Bank of Plant Genetic Resources (PGRI) PARC Pakistan.

\section{References}

Ali, K., Khan, N., Rahman, I.-U., Khan, W., Ali, M., Uddin, N., \& Nisar, M. (2018). The ethnobotanical domain of the Swat Valley, Pakistan. Journal of Ethnobiology and Ethnomedicine, 14(1), 39.

Baik, B.-K., \& Ullrich, S. E. (2008). Barley for food: Characteristics, improvement, and renewed interest. Journal of Cereal Science, 48(2), 233-242.

Baloch, A. W., Ali, M., Baloch, A. M., Mangan, B.-U.-N., \& Song, W. (2014). Genetic diversity and structure analysis based on hordein protein polymorphism in barley landrace populations from Jordan. Pakistan Journal of Botany, 46(4), 1397-1402.

Derbew, S., Mohammed, H., \& Urage, E. (2013). Phenotypic diversity for qualitative characters of barley (Hordeum vulgare L.) landrace collections from Southern Ethiopia. International Journal of Science and Research, 2(9), $34-40$.

Ebrahim, S., Shiferaw, E., \& Hailu, F. (2015). Evaluation of genetic diversity in barley (Hordeum vulgare L.) from Wollo high land areas using agromorphological traits and hordein. African Journal of Biotechnology, 14(22), 1886-1896.

Ferreira, J. R., Pereira, J. F., Turchetto, C., Minella, E., Consoli, L., \& Delatorre, C. A. (2016). Assessment of genetic diversity in Brazilian barley using SSR markers. Genetics and Molecular Biology, 39(1), 86-96.

Hassan, N., Wadood, S., Ullah, H., Zahoor, M., Khan, M., Khan, A., \& Nisar, M. (2016). Estimation of genetic diversity in Cupressus sempervirens growing in different ecological zones of Malakand Division, KP, Pakistan. International Journal of Biosciences, 8, 15-21.

Hua, W., Zhang, X., Zhu, J., Shang, Y., Wang, J., Jia, Q., Li, C., \& Yang, J. (2014). A study of genetic diversity of colored barley (Hordeum vulgare L.) using SSR markers. Genetic Resources and Crop Evolution, 62(3), 395-406.

Ivandic, V., Thomas, W. T. B., Nevo, E., Zhang, Z., \& Forster, B. P. (2003). Associations of simple sequence repeats with quantitative trait variation including biotic and abiotic stress tolerance in Hordeum spontaneum. Plant Breeding, 122(4), 300-304. 
Khodayari, H., Saeidi, H., Roofigar, A. A., Rahiminejad, M. R., Pourkheirandish, M., \& Komatsuda, T. (2012). Genetic diversity of cultivated barley landraces in Iran measured using microsatellites. International Journal of Bioscience, Biochemistry and Bioinformatics, 2, 287-290.

Ladizinsky, G., \& Hymowitz, T. (1979). Seed protein electrophoresis in taxonomic and evolutionary studies. Theoretical and Applied Genetics, 54(4), 145-151.

Ledovskoy, Y, Abugalieva, S., \& Turuspekov, Y. (2010). Comparative assessment of the genetic variation in wild and cultivated barley based on SSR markers. Asian and Australasian Journal of Plant Science and Biotechnology, 4, 21-26.

Mzid, R., Chibani, F., Ayed, R. B., Hanana, M., Breidi, J., Kabalan, R., El-Hajj, S., Machlab, H., Rebai, A., \& Chalak, L. (2016). Genetic diversity in barley landraces (Hordeum vulgare L. subsp. vulgare) originated from Crescent Fertile region as detected by seed storage proteins. Journal of Genetics, 95(3), 733-739.

Nandha, P. S., \& Singh, J. (2013). Comparative assessment of genetic diversity between wild and cultivated barley using gSSR and EST-SSR markers. Plant Breeding, 133(1), 28-35.

Sipahi, H., Akar, T., Yıldı, M. A., \& Sayım, İ. (2010). Determination of genetic variation and relationship in Turkish barley cultivars by hordein and RAPD markers. Turkish Journal of Field Crops, 15(2), 108-113.
Toivonen, M., Herzon, I., \& Helenius, J. (2013). Environmental fallows as a new policy tool to safeguard farmland biodiversity in Finland. Biological Conservation, $159,355-366$

Tsen, C. C. (1985). Amino acid composition and biological value of cereal germs. In: Amino acid composition and biological value of cereal proteins, Springer. Pp. 453-466.

Vapa, L., \& Radović, D. (1998). Genetics and molecular biology of barley hordeins. Cereal Research Communications, 26, 31-38.

Weber, B., Collins, C., Robbins, C., Magenis, R. E., Delaney, A. D., Gray, J. W., \& Hayden, M. R. (1990). Characterization and organization of DNA sequences adjacent to the human telomere associated repeat (TTAGGG)n. Nucleic Acids Research, 18(11), 3353-3361.

Yahiaoui, S., Igartua, E., Moralejo, M., Ramsay, L., Molina-Cano, J. L., Ciudad, F. J., Lasa, J. M., Gracia, M. P., \& Casas, A. M. (2007). Patterns of genetic and eco-geographical diversity in Spanish barleys. Theoretical and Applied Genetics, 116(2), 271-282. 